\title{
First record of Phaenopsectra flavipes (Meigen, 1818) in Slovakia with notes on its ecology
}

Veronika Štillová ${ }^{1}$, Marcela Přidalová ${ }^{1}$, Milan Novikmec ${ }^{2}$, Marek Svitok ${ }^{2}$ and Ladislav Hamerlík ${ }^{1,3 *}$

\footnotetext{
1) Department of Biology and Ecology, Matej Bel University, Tajovského 40, SK-974 01 Banská Bystrica, Slovakia, E-mail: stillova93@gmail.com, ladislav.hamerlik@gmail.com

${ }^{2)}$ Department of Biology and General Ecology, Faculty of Ecology and Environmental Sciences, Technical University in Zvolen, T. G. Masaryka 24, SK-960 53 Zvolen, Slovakia

3) Institute of Geological Sciences, Polish Academy of Sciences, Twarda 51/55, 00-818 Warsaw, Poland

*corresponding author
}

Phaenopsectra flavipes (Meigen, 1818) is a chironomid with a Holarctic distribution and is commonly found throughout Europe (Sæther and Spies 2013). Larvae are widespread in slowly flowing or stagnant waters but are never numerous (Moller Pillot 2009). They prefer to inhabit stems and leaves of aquatic plants; findings from sandy and stony bottoms are scarce (Moller Pillot 2009). The larvae are most likely primarily detritivores, however, they can feed as grazers and perhaps also as active filter feeders (Moog 2002). In Slovakia, only larvae of the Phaenopsectra genus have been reported to date, thus Bitušík and Brabec (2009) did not include P. flavipes in the check list of the Slovak Chironomidae and Sæther and Spies (2013) list the presence of the species as doubtful. During our large-scale survey of the Slovakian ponds (BIOPOND, for details see Novikmec et al. 2016), pupal exuvia of P. flavipes were found, resulting in the first official record of this species in Slovakia. In the present paper we bring details of the finding with information on the environmental conditions of the habitats of occurrence.

\section{Diptera: Chironomidae: Chironominae: Chironomini: Phaenopsectra flavipes (Meigen, 1818)}

Material examined: a pond close to Moškovec village (Fig. 1a), C Slovakia, 48.9492222 N, 18.8475556 E, 440 m a. s. 1., 1 pupal exuvia, 29. 8. 2013, leg. L. Hamerlík, det. et coll. V. Štillová. Larvae of Phaenopsectra most likely belonging to the same species were collected from two other sites: a pond near Holiša
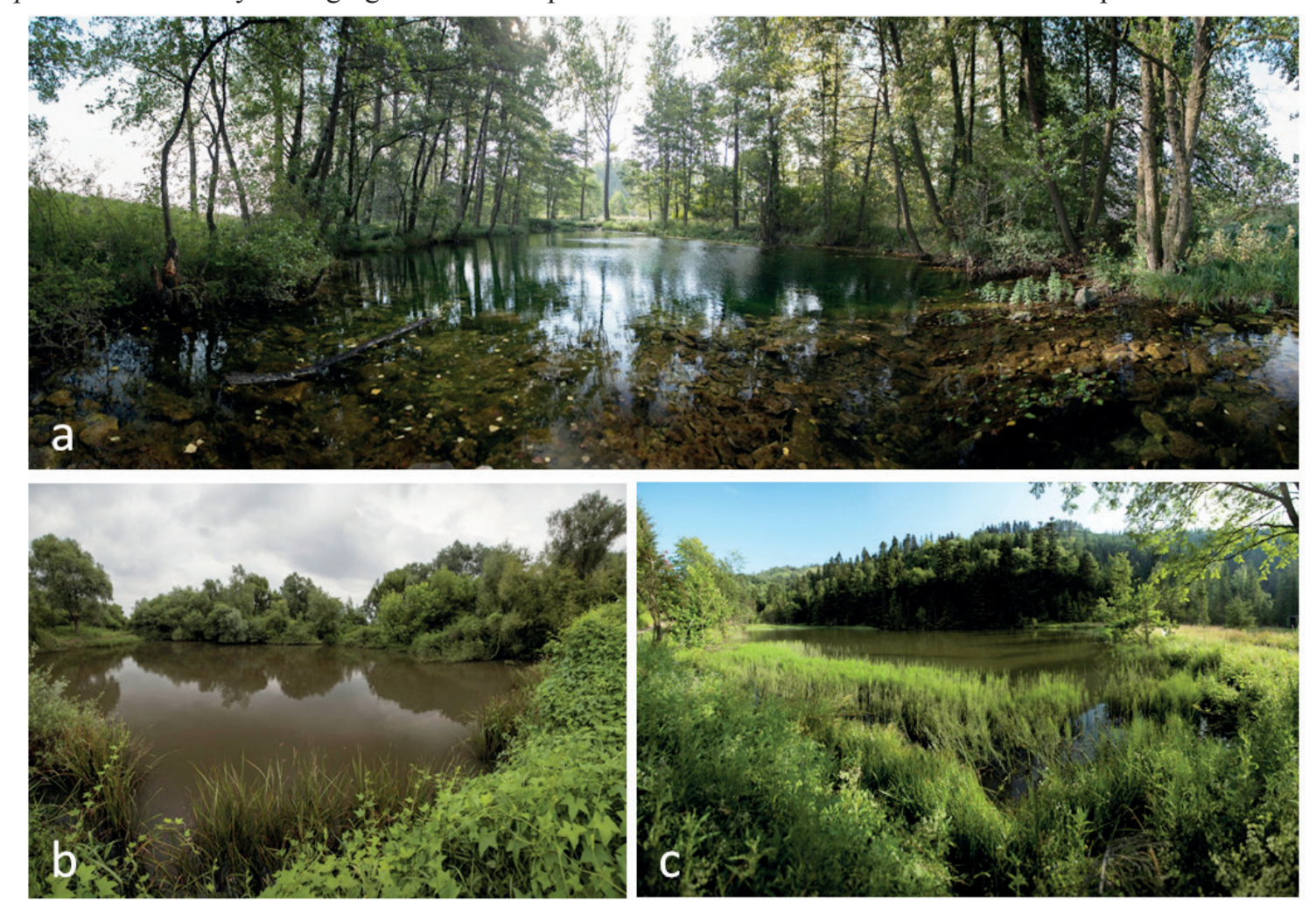

Figure 1. Pictures of the sites of the first record of Phaenopsectra flavipes: a pond near Moškovec with the occurrence of the pupal exuvia (a) and the ponds near Holiša (b) and Stráňany (c) where larvae of Phaenopsectra sp. were recorded. Photo M. Svitok. 
(Fig. 1b), C Slovakia, 48.3068611 N, 19.7512222 E, 175 m a. s. 1., 10. 7.2013 (1 larva), and a pond next to Stráňany (Fig. 1c), E Slovakia, 48.3430667 N, 20.5265528 E, 824 m a. s. 1., 16. 7. 2013 (2 larvae).

The material was collected using a combination of drift sampling (to obtain pupal exuviae) and the PLOCH method (Oertli et al. 2005) to collect larvae. Preimaginal stages were picked, mounted as permanent slides and identified using keys by Langton and Visser (2003) and Wiederholm (1983). The material is deposited at the Department of Biology and Ecology, Matej Bel University, Banská Bystrica, Slovakia.

In our study, all three sampling sites (ponds) with the occurrence of Phaenopsectra harboured fish and macrophytes with Berula erecta, Equisetum fluviatile, Eriophorum angustifolium, and Potamogeton berchtoldii being the most dominant (R. Hrivnák, pers. comm). Fine sediment constituted the bottom of ponds near Holiša and Stráňany, while the bottom of the Moškovec pond was more heterogeneous, consisting of coarse mineral substrate, gravel and fine sediment $(50 \%, 30 \%$, and $20 \%$, respectively). The catchment area of the Moškovec pond was dominated primarily by grassland, while that of Stráňany and Holiša were dominated by forested and urbanized land, respectively. Other specific hydromorphological and physio-chemical data for each pond can be found in Table 1 .

Table 1. Hydromorphological and physio-chemical characteristics of the studied ponds and land use in the catchment.

\begin{tabular}{|c|c|c|c|c|}
\hline Variable/ site name & Unit & Moškovec & Holiša & Stráňany \\
\hline Altitude & m a.s. 1. & 440 & 175 & 824 \\
\hline Area & $\mathrm{m}^{2}$ & 117 & 78 & 7,612 \\
\hline Depth & $\mathrm{cm}$ & 143 & 78 & 178 \\
\hline \multicolumn{5}{|l|}{ Substrate } \\
\hline Fine & $\%$ & 20 & 100 & 100 \\
\hline Sand & $\%$ & 0 & 0 & 0 \\
\hline Gravel & $\%$ & 30 & 0 & 0 \\
\hline Coarse & $\%$ & 50 & 0 & 0 \\
\hline \multicolumn{5}{|l|}{ Water chemistry } \\
\hline $\mathrm{pH}$ & & 7.3 & 7.6 & 8.1 \\
\hline Conductivity & $\mu \mathrm{S} \mathrm{cm}^{-1}$ & 668 & 596 & 239 \\
\hline $\mathrm{Ca}$ & $\mathrm{mg} \mathrm{L}^{-1}$ & 31.88 & 18.85 & 14.36 \\
\hline $\mathrm{Fe}$ & $\mu \mathrm{g} \mathrm{L}^{-1}$ & 0.5 & 17 & 32 \\
\hline $\mathrm{Mg}$ & $\mu \mathrm{g} \mathrm{L}^{-1}$ & 26.42 & 12.92 & 7.12 \\
\hline $\mathrm{Mn}$ & $\mu \mathrm{g} \mathrm{L}^{-1}$ & 1.25 & 219.74 & 11.97 \\
\hline $\mathrm{P}$ & $\mu \mathrm{g} \mathrm{L}^{-1}$ & 15 & 172 & 0.5 \\
\hline $\mathrm{NH}_{4}$ & $m g \mathrm{~L}^{-1}$ & 0.16 & 0.84 & 0.63 \\
\hline $\mathrm{NO}_{3}$ & $m g L^{-1}$ & 1.09 & 0.35 & 0.9 \\
\hline $\mathrm{NO}_{2}$ & $m g L^{-1}$ & 0.03 & 0.06 & 0 \\
\hline $\mathrm{PO}_{4}$ & $\operatorname{mg~L} \mathrm{L}^{-1}$ & 0.3 & 0.39 & 0.05 \\
\hline \multicolumn{5}{|l|}{ Land use } \\
\hline Arable land & $\%$ & 0 & 0 & 0 \\
\hline Forests/shrubs & $\%$ & 0 & 8 & 87 \\
\hline Grassland & $\%$ & 67 & 22 & 12 \\
\hline Urbanized & $\%$ & 33 & 70 & 0 \\
\hline Waterbodies & $\%$ & 0 & 0 & 1 \\
\hline
\end{tabular}




\section{Acknowledgements}

We are very grateful to Richard Hrivnák, Institute of Botany, Slovak Academy of Sciences, who provided us the list of macrophytes from the surveyed ponds. This paper was supported by project ITMS 26210120024 "Renewal and development of infrastructure for ecological and environmental research at UMB" and by the Slovak Research and Development Agency under the contract No. APVV-0059-11.

\section{References}

Bitušík, P. and Brabec, K. 2009. Chironomidae Newman, 1834. - In Jedlička L., Stloukalová, V. and M. Kúdela (Eds.) Checklist of Diptera of the Czech Republic and Slovakia. Electronic version 2.

Langton, P.H. and Visser, H. 2003. Chironomidae exuviae. A key to pupal exuviae of the West Palaearctic Region. Interactive Identification System for the Europaean Limnofauna (IISEL). World Biodiversity Database, CD-ROM Series.

Moller Pillot, H.K.M. 2009. Chironomidae Larvae, Volume 2: Biology and Ecology of the Chironomini. KNNV Publishing, Zeist, The Netherlands, 270 pp.

Moog, O. (Ed.) 2002. Fauna Aquatica Austriaca, Edition 2002. A Comprehensive Species Inventory of Austrian Aquatic Organisms with Ecological Notes. Wasserwirtschaftskataster, Bundesministerium für Land- und Forstwirtschaft, Wien.

Novikmec, M., Hamerlík, L., Kočický, D., Hrivnák, R., Kochjarová, J., Ot’ahel’ová, H., Pal'ove-Balang, P. and Svitok, M. 2016. Ponds and their catchments: size relationships and influence of land use across multiple spatial scales. - Hydrobiologia 774: 155-166.

Oertli, B., Auderset Joye, D., Castella, E., Juge, R., Lehmann, A. and Lachavanne, J.B. 2005. PLOCH: a standardized method for sampling and assessing the biodiversity in ponds. - Aquatic Conservation: Marine and Freshwater Ecosystems 15: 665-679.

Sæther, O. A. and Spies M. 2013. Fauna Europaea: Chironomidae.- In Beuk, P, Pape, T. and de Jong, Y.S.D.M. (Eds.): Fauna Europaea: Diptera, Nematocera. Fauna Europaea version 2.6, http>//www. faunaeur.org

Wiederholm, T. (Ed.) 1983. Chironomidae of the Holarctic Region. Keys and Diagnoses. Part I, Larvae. Entomologica Scandinavica Supplement 19: 1-457.

Article submitted 21. September 2016, accepted by Alyssa M. Anderson 20. October 2016, published 27. October 2016. 